Article

\title{
Economic Transitions in South Africa's Secondary Cities: Governing Mine Closures
}

\author{
Lochner Marais ${ }^{1,3,} *$, Verna $\mathrm{Nel}^{2}$, Kholisa Rani $^{3}$, Deidré van Rooyen ${ }^{3}$, Kentse Sesele ${ }^{3}$, Phia van der Watt ${ }^{3}$ \\ and Lyndon du Plessis ${ }^{4}$ \\ ${ }^{1}$ Sustainable Minerals Institute, University of Queensland, Australia; E-Mail: maraisjgl@ufs.ac.za \\ 2 Department of Urban and Regional Planning, University of the Free State, South Africa; E-Mail: nelvj@ufs.ac.za \\ ${ }^{3}$ Centre for Development Support, University of the Free State, South Africa; E-Mails: sigenuk@ufs.ac.za (K.R.), \\ griesd@ufs.ac.za (D.v.R.), kennywenzi@gmail.com (K.S.), phiavdwatt@gmail.com (P.v.d.W.) \\ ${ }^{4}$ Department of Public Administration and Management, University of the Free State, South Africa; \\ E-Mail: dplessIm@ufs.ac.za \\ * Corresponding author
}

Submitted: 20 January 2021 | Accepted: 19 March 2021 | Published: 25 June 2021

\begin{abstract}
Many South African secondary cities depend on a single economic sector, often mining or manufacturing. This makes them vulnerable to economic change and national decision-making. We describe change in three secondary cities-Emalahleni, Matjhabeng and Newcastle-all at different phases of economic transition due to imminent mine closure. We investigate the way local governance and planning are dealing with the change. We draw on concepts from institutional economics and evolutionary governance theory, material from strategic planning documents, and approximately 50 key informant interviews. We show how difficult it is to steer economic planning during economic transitions, and we demonstrate how both economic change and governance are path-dependent. Path dependency in South Africa's mining towns has several causes: the colonial influence, which emphasised extraction and neglected beneficiation; the dominance of a single sector; the long-term problems created by mining; and the lack of the skills needed to bring about economic change. The local governments' continuing reliance on the New Public Management paradigm, which focuses on steering as opposed to building networks, compounds the problem, along with poor governance, inadequate local capacity and inappropriate intergovernmental relations. Of the three towns, only Newcastle has shown signs of taking a new path.
\end{abstract}

\section{Keywords}

economic transition; path dependency; secondary city; steering; New Public Management; mine closure

\section{Issue}

This article is part of the issue "Steering in Governance: Evolutionary Perspectives" edited by Kristof Van Assche (University of Alberta, Canada / University of Bonn, Germany) and Raoul Beunen (Open University, The Netherlands).

(C) 2021 by the authors; licensee Cogitatio (Lisbon, Portugal). This article is licensed under a Creative Commons Attribution 4.0 International License (CC BY).

\section{Introduction}

Research on secondary cities in the developing world has focused mostly on their economic role and the spatial distribution of their population. These cities play important regional development roles and have strong links with the global economy. But many of them lack economic diversity and have global connections in only one economic sector. Because of the global volatility in mining and manufacturing on which many of them depend, their future is not clear. This is true of South African secondary cities, whose smaller economies (in comparison with those of the country's metropolitan cities) make them vulnerable to changes in technology and in local and national government decisions (Marais, 2016; Marais et al., 2016). Governing a secondary city and managing its economic transitions is indeed a challenge. 
Avis $(2016$, p. 1) defines urban governance as the "process by which governments (local, regional and national) and stakeholders collectively decide how to plan, finance and manage urban areas." However, the literature on governance outlines a variety of approaches to governance (Klijn, 2008; Rhodes, 1997) and there is substantial debate about the meaning of the concept. We do not have space to elaborate on these but we emphasise three critical attributes relevant to this article: Governance has become increasingly complex and difficult as multiple actors play a role; governance changes are mostly slow; and because of the complexity and slowness it is questionable whether governance can steer transitions.

The challenge for many of South Africa's secondary cities is to shift from their dependence on manufacturing and mining to more diverse economies, to overcome their vulnerability to national government decisions, and to adjust to a global economy that requires high-level technological skills. These changes will require appropriate governance approaches. Consequently, all South African municipalities must develop strategic plans (called integrated development plans [IDPs]). These usually include specific sector plans for spatial, housing and economic development. The idea for these plans was, as Harrison (2001) explains, to a large extent based on the New Public Management (NPM) paradigm, which emphasises 'steering' (setting objectives) rather than 'rowing' (implementation).

We make two main arguments in this article. We argue that South Africa's governance approach is still primarily rooted in NPM, underplaying the relationship between actors and overemphasising steering. The NPM reinforces the existing path dependency and the rigidity associated with interdependencies and creates governance informalities. This, coupled with inadequate local capacities and inappropriate intergovernmental relations, makes local economic transitions difficult. We argue further that economic transition is particularly difficult for mining towns attempting to diversify their economy, because the mines create a false sense of security and interdependency. The article contributes by linking the literature on economic transitions and governance. In many cases, this literature appears in journals with different theoretical and disciplinary approaches.

\section{Evolutionary Governance Theory, Economic Transitions and Steering}

This literature review brings together studies on economic transitions (North, 1990, 2005; Van Assche et al., 2014, 2016) and on governance (Dunleavy et al., 2005; Garud \& Karnoe, 2001; Klijn, 2008; Kuhlmann et al., 2008; Stoker, 2006). In discussing the institutional context ('the rules of the game') in this article, we borrow extensively from North (1990, 2005). For North, institutional change (or rule change) and technological change are the foundation of economic change. He asserts that change is slow, path-dependent and usually leads to lock-ins. He describes 'path dependence' as the way institutions and beliefs from the past influence choices in the present and maintains that constraints on choices in the present result from historical experiences (North, 2005, p. 21). For new institutional economists, the history, societal beliefs and institutions are central to understanding economic change and society's response. In its simplest form, path dependency means that institutions constrain the future; more comprehensively it means that "the institutions that have accumulated give rise to organisations whose survival depends on the perpetuation of those institutions and which hence will devote resources to preventing any alteration" (North, 2005, p. 51). North (1990) says path dependencies associated with institutions are usually more complicated than those associated with technology. Path dependency develops because there is a gap between intentions and outcomes and because it is difficult to reverse long-term directions. North (1990) uses the term 'lock-in' to describe slow change and the inability to escape history. Lock-ins occur when change is not just slow but virtually impossible.

Building on the ideas of North, evolutionary governance theory describes slow change in governance (Van Assche et al., 2014, 2016). It links economic change and governance. It draws its ideas from biological evolution and from social theories like new institutional economics (from the work of North), complexity theory and actor-network theory. Key concepts are slow change (although it can sometimes be abrupt), non-linearity, power relations and governance seen as evolving. Evolutionary governance theory sees governance as a central aspect of politics and distinguishes three types of dependency: path dependency, goal dependency, and interdependency.

In this article we are interested in two of these dependencies: interdependencies and path dependencies. Interdependencies can originate from path dependency and can be constructive or damaging. Current organisations and their rules and associations originate from historical interactions and expectations (Greif, 2006). On the negative side these relationships can lead to rigidity, conflict and power plays, preventing change, but on the positive side to collaboration, partnerships, expertise and resources (Van Assche et al., 2016). Generally, interdependencies depend on cooperation, responsibility and trust. They can also contribute to governance networking or what Klijn et al. (1995) refer to as 'policy networking' or 'network steering.' Network steering assumes an understanding of actors and their relationships, resources, institutions and perceptions. Klijn et al. $(1995$, p. 439) say the main consequence of policy networking or network steering is that "when a (governmental) actor tries to govern policy processes, he has to take the characteristics of this network into account." In addition to obliging actors to understand the network, network steering is also dependent on resource 
distribution, the rules of resource distribution within the network and perceptions within the network.

Understanding the sources of path dependency is crucial for planners. They need to take cognisance of the historical nature of governance systems and their interlocking chains of causation. Many governance systems reproduce themselves in complex ways, along a multiplicity of paths that all have different possible outcomes. Earlier studies of path dependency were mainly at the national level or on specific issues like technology change (North, 1990). Increasingly there is a tendency to study it at the local level, and evolutionary governance theory has integrated the concepts of economic change and politics.

The question now is what role strategic planning and governance play in path dependencies and interdependencies. Garud and Karnoe (2001) emphasise that it is possible to create new paths (through strategic planning) despite path dependence. Klijn (2008) identifies four ways in which governance can contribute to strategic planning: good governance and administration, the NPM paradigm, intergovernmental relations, and networks. In this article we are primarily interested in contrasting governance that relies on the NPM paradigm with governance that relies on networks. However, the other two approaches (good governance and administration, and intergovernmental relations) remain a central part of our framework for understanding the governance of economic transitions. Intergovernmental relations and the varying levels of interdependence are crucial for understanding governance in South Africa. Good governance remains a challenge here.

The rise of NPM in the 1980s was a prime example of prioritising steering in the public sector. NPM emphasised setting goals, developing outcomes-based programmes, distinguishing between politics and administration, making government more business-like, instituting performance-based payments and delinking policy and implementation (creating implementation vehicles; Stoker, 2006). The German government called their model of NPM the 'New Steering Model' (Neues Steuerungsmodell; Kuhlmann et al., 2008). Many governments have used this approach to 'modernise' their public service and to move away from the Weberian bureaucratic model of public administration (Stoker, 2006, p. 45). Evaluations point to a range of achievements, such as savings and efficiency gains, customer orientation and service quality (Kuhlmann et al., 2008). But concerns remain, among them the inability to achieve an appropriate separation between politics and administration, resistance to implementation, inadequate cost savings in staff and time, failure to contribute to better decision-making despite the rhetoric, continued conflict between centralised and decentralised management, little reduction in political interference, and only partial efficiency gains (Dunleavy et al., 2005; Kuhlmann et al., 2008). In their evaluation of the New Steering Model, Kuhlmann et al. (2008, p. 859) conclude that "with its schematic dualism of politics and administration, [it] is conceptually misleading and stands in stark contrast to the reality of political decision making," and Stoker (2006, p. 46) argues that it requires politicians "to be separated from their party and other political colleagues and connections to exercise good judgment." The NPM paradigm has also been criticised for limited theoretical grounding, not taking historical evidence into account, and using evidence selectively (Hood \& Peters, 2004).

In contrast, other understandings of governance stress the relationships between institutions like networks (Klijn, 2008; Klijn et al., 1995). Stoker (2006, p. 41) argues that the state should "steer society in new ways through the development of complex networks" and use "more bottom-up approaches to decision making." He says the trend towards using networks in governance means that a wider range of participants will be seen as "legitimate members of the decision-making process in the context of considerable uncertainty and complexity." This kind of governance differs from NPM in not presetting targets but negotiating them with the actors, and in emphasising rights and responsibilities rather than targets. However, policy networking or network steering is not an appropriate response per se. Klijn et al. (1995) say the margins are not wide; only limited resources are available and self-interests prevail. There is no guarantee that network steering provides better outcomes than other processes, but this indirect steering could have some benefits in contrast to direct policy approaches.

Above, we discussed how governance interacts with or steers economic transitions by focusing on formal governance and transition processes. However, governance also interacts with political transition and vice versa and can be formal or informal. Informality is now a core component of urban governance worldwide (Sarmiento \& Tilly, 2018; Van Assche et al., 2013). In a book review, Bejacovic (2016, p. 464) writes that "unofficial production, nonregistration of economic activities and/or corruption may be deemed the solution rather than the problem because such practices might be seen as the only way in which the state can be made to work." Informality can play a range of roles, such as replacing the state by providing services the state should deliver, blurring the lines between the state and the community, getting involved in confrontations with the law (not following procedure), and engaging in institutionalised corruption (Polese, 2016). Furthermore, notions of formality and informality change frequently, making such a distinction difficult and influence other institutions in complex interactions (Van Assche et al., 2013)

\section{The Case Studies}

Our discussion in this article is based on case studies of three secondary cities-Emalahleni, Matjhabeng and Newcastle-chosen to represent three stages of economic transition. Emalahleni, in the Mpumalanga Province, a coal-mining town and the heart of South 
Africa's coal-generated electricity system, is facing probable major economic transition in the next decade because of the global and local need for cleaner energy. Matjhabeng, a gold mining town in the Free State Province, has seen three decades of decline in gold production and been unable to find an alternative economic base. Newcastle, a coal-mining town in northern Kwazulu-Natal, has managed an economic transition away from coal and steel and towards manufacturing but has lately struggled to keep up the momentum. The case studies were conducted between 2017 and 2019, using data from Statistics South Africa and Global Insight, planning documents, and 52 interviews with key informants: political role players, mining company staff, municipal officials responsible for planning, and representatives from NGOs. The informants were selected via snowball sampling. We used thematic analysis to analyse the interview transcripts.

Figure 1 shows the percentage of seats that the African National Congress (ANC), which has the majority in South Africa's parliament, obtained in local government elections in these three towns.

In Emalahleni and Matjhabeng, the ANC's support has declined since 2006, with the ANC holding $60 \%$ of the seats in Emalahleni and nearly $65 \%$ in Matjhabeng. In Newcastle, the ANC has increased its share of seats since 2000 and now has $61 \%$ of the seats. The decline in the first two was the result of a national trend, while the rise in Newcastle was primarily due to the Inkatha Freedom Party's disintegration. Historically the ANC in Newcastle had to form coalitions with other parties or collaborate with them, because its majority was slim; since 2016 it has not had to do this.

\section{The Three Cities}

Secondary cities in South Africa, referred to as 'intermediate cities,' have no specific legal status as such. South African legislation recognises Category A municipalities (eight metropolitan areas), Category B municipalities (226 local municipalities) and Category $C$ municipalities (44 district municipalities). A district municipality usually consists of three to six local municipalities. Recent policy development has established the Intermediate City Municipality Support Programme (2018). The programme subdivides the 39 secondary cities into five categories: large/semi-diverse (4), manufacturing (9), mining (10), service centres (10), and low GVA and high-density areas (6; South African Cities Network, 2020) and requires these cities to provide appropriate strategic plans and sound financial management.

The local strategic plans (IDPs) for municipalities in South Africa include, among other things, sectoral plans for housing, spatial development and local economic development (LED). The IDPs are usually very good at setting targets and providing plans for steering, in line with NPM ideas. This approach to strategic planning, coupled with political power play and local governments' severe capacity constraints, lies at the heart of the problem when it comes to economic transition. Deteriorating municipal finances, inadequate municipal financial management (Auditor General of South Africa, 2020) and the large number of local protests point to serious governance problems (Westoby \& Botes, 2020).

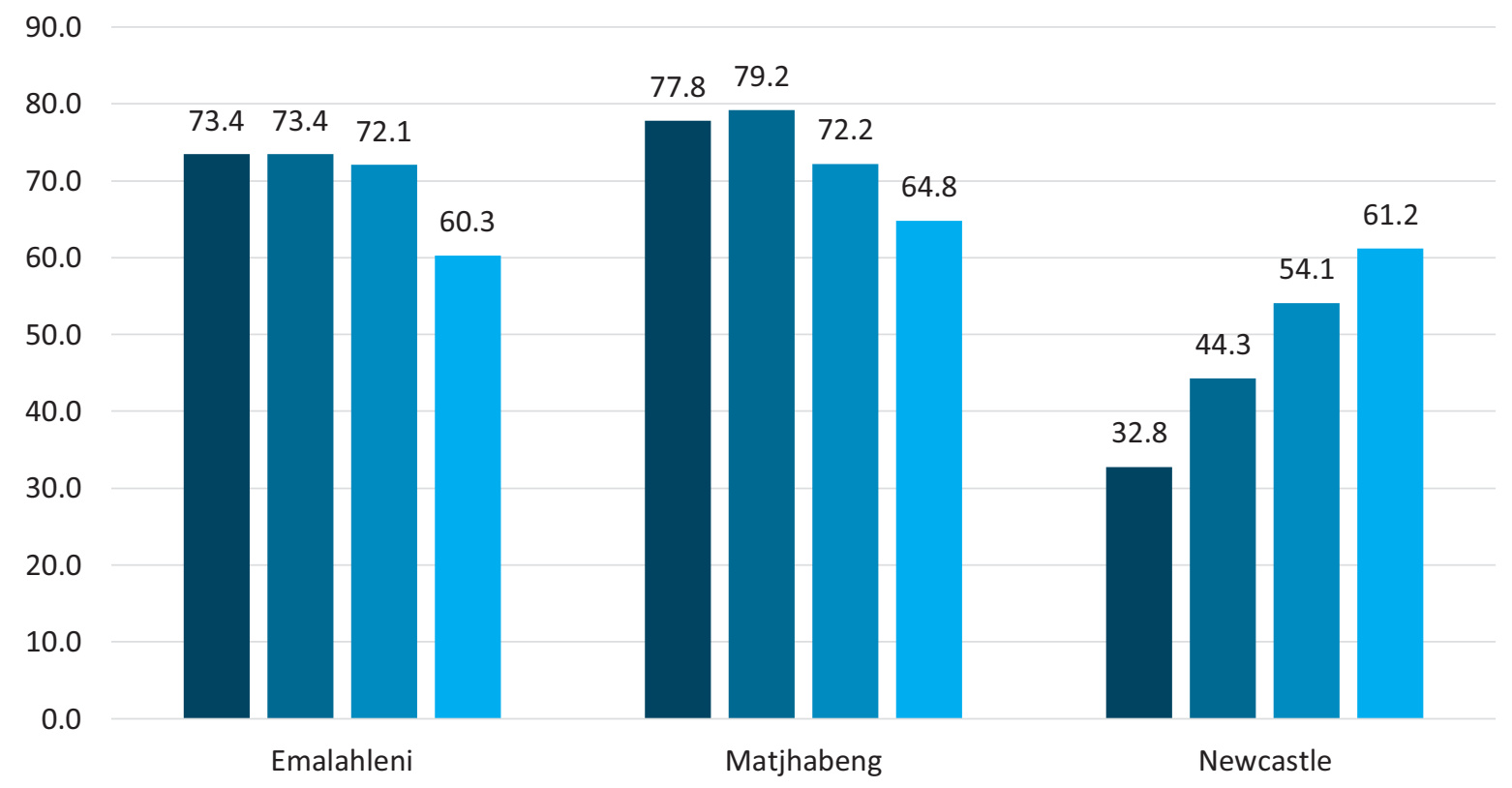

m seats for ANC, 2000 \% seats for ANC, 2006 \% seats for ANC, 2011 \% seats for ANC, 2016

Figure 1. Local government election results in Emalahleni, Matjhabeng and Newsactle, 2000, 2006, 2011 and 2016. Source: Electoral Commission of South Africa (n.d.). 


\subsection{Emalahleni}

Witbank, later renamed Emalahleni ('place of coal'), was declared a town in 1903. A rail link with the goldfields on the Witwatersrand opened shortly after that, enabling the mines to provide coal at scale and for low prices. By the early 1930s the first coal-fired power station was operating. In the 1960s Anglo American created Africa's first private steel mill in Witbank. Today about $70 \%$ of South Africa's coal is used locally in coal-fired power stations and the rest is exported via Richards Bay. The local economy depends on coal and the coal-fired power stations that provide approximately $40 \%$ of South Africa's energy. But the pollution associated with mining and the power stations has made Emalahleni one of the country's pollution hotspots. Economic growth between 1996 and 2018 averaged $1.4 \%$ per annum and the area benefited from the commodity boom of the 2000s. The population grew by $3.3 \%$ per annum and totalled 460,000 people in 2016. Despite these high levels of economic growth, the local government is struggling to provide services and cannot pay its electricity bill with Eskom, the national electricity utility (Campbell et al., 2016, 2017). Emalahleni Local Municipality has not received unqualified audits for the past five financial years. The current state of municipal finance makes it unlikely there will be any contribution from the municipality to help manage mine closure (Hendriks, 2022). The provincial government had to appoint an administrator on two occasions to manage the municipality on behalf of the Council. A previous administrator noted that municipal councillors and officials had stolen from the municipality and driven it into bankruptcy (Campbell et al., 2016, 2017).

The municipality also struggles to provide adequate services and housing. The result is the construction of large numbers of informal dwellings to counter the municipality's inability to deal with the housing problem. None of the seven key performance areas in the IDP takes into account mine decline and closure as a future threat. The IDP uses the word 'closure' only once (Emalahleni Local Municipality, 2021). In their social and labour plans the mines responded by setting up a closure reference group. Beyond this structure, no real plans are available. Interviewees seldom raised the issue of possible mine closure and its implications, as the main concern was dealing with the effects of mining growth. Instead, we heard comments like "the municipality is not coping," "there are problems with growing informal settlements because of mine employees," and "the mines should fix the potholes." They also referred to the large influx of people. Because of these problems, one of the mining companies is now selling water to the municipality.

With the worldwide shift to renewables and cleaner forms of energy, the local and international demand for coal is likely to decline. The dollar price of coal was at a global high at the end of 2019 but has declined steadily since then (the deteriorating value of the rand to the dollar has buffered this slightly). Like most other nations, South Africa has signed the Paris Agreement. Consequently, the Department of Energy is actively promoting renewable energy and Eskom is likely to scale down its old coal plants. These decisions will have devastating effects on the economy of Emalahleni, but there has been no concerted effort at the local level to manage the risks. The municipality largely ignores the potential consequences of mine and power station closure. A national effort to plan a just transition (ensuring that renewable energy does not create unemployment among mineworkers) is underway, but it is not clear to what degree these plans consider the complexities of the local governance (Marais et al., 2022).

\subsection{Matjhabeng}

The South African Government and Anglo American established the town of Welkom in 1947, when mining companies started to sink shafts in the area. This initiated the Free State Goldfields, which became Matjhabeng under the post-apartheid dispensation (after 1994). At its height in the mid-1980s the area produced more than $25 \%$ of the gold in the free world and employed 180,000 mineworkers (Marais, 2013a, 2013b). However, mine decline and closure became a reality from the early 1990s, because of the depletion of the gold reserves, the cost of deep mining, a rise in wages and stricter health and safety requirements. Although mining and mine employment is still dominant in the area, there are only about 25,000 mineworkers left (Denoon-Stevens, 2019). Between 1996 and 2018 the economy declined by $3 \%$ per annum, but gold mining was still contributing $45 \%$ of GVA in 2018 (down from $62 \%$ in 1996). The size of the economy in 2018 was only $55 \%$ of what it had been in 1996. Economic decline has had detrimental social consequences in the area (Sesele et al., 2021) and has also resulted in a drop in the population from 480,000 in 1996 to 430,000 in 2016.

Over the years, various governance approaches have tried to revamp the economy of the area (Marais, 2013b). In the 1960s, the provincial government established a commission to prevent the development of a ghost town once mining ended (Marais \& Nel, 2016). In the late 1980 s, several of the towns in the Goldfields area established a separate development unit-in line with the NPM approach - which emphasises that implementation should take place outside the ambit of local government (Marais, 2013b). The new political rulers in the post-apartheid dispensation dismantled this institution in the mid-1990s, but a similar attempt followed in the early 2000s. These attempts have been hampered by political infighting and unrealistic plans. Many mayors did not complete their terms and the turnover of municipal managers has been extraordinarily high (Sesele, 2020). Like Emalahleni, Matjhabeng Local Municipality has not received unqualified audits for the past five financial years. Today, a regional development agency is operating at the district level, but it is not clear how successful 
it is. The economic development function is within the ambit of the Matjhabeng Council.

In 2019, with the financial aid of the mines, Matjhabeng contracted a private service provider to create a LED plan to form part of the IDP. However, the plan assumes a large percentage of funding from other spheres of government as Matjhabeng's financial situation is dire. Most respondents were extremely proud of this plan that had been produced to deal with the economic situation. In most interviews, it was the first topic raised by interviewees. One interviewee, referring to this dependence on other spheres of government, asked, "When will the provincial and national government take us seriously?" Another said: "We have a plan now; the national government should now come to the party"emphasising the importance of having a plan or steering and the need for national government support based on the plan. The interviewees seemed to believe that having a plan automatically means that action will result. Implementation will be hindered not only by lack of government support but also by lack of institutional capacity. Furthermore, the plan does not refer to the regional service role developed around Welkom (the municipality's main urban area), which is central to strategic plans for intermediate city municipalities (Marais et al., 2016). The need to find an alternative 'big' plan for mining makes the planners overlook the role of regional services. The LED directorate's capacity in the municipality is limited, with not enough staff members and without a single economist. A functional directorate should create networks within the government and between the government and the private sector. Although relationships with the business community have improved lately, there is scant evidence of joint projects and programmes outside managing an increase in crime.

Despite the ANC's majority in the Council, Matjhabeng has been politically unstable, as is evident from the fact that none of the mayors in the last three terms (2001-2006, 2006-2011 and 2011-2016) completed their terms. The municipality has had more than ten municipal managers over the last 20 years, suggesting a constant conflict between the political office bearers and the technocrats.

\subsection{Newcastle}

The discovery of coal near Newcastle in 1865 laid the foundation for the establishment of the town. By the 1960 s coal mining was the main reason why Iscor (a previous state corporation manufacturing steel in South Africa) created a new steel mill in 1968. Iscor was also prominent as an estate developer and constructed hundreds of houses for its employees in Newcastle. By the mid-1980s Newcastle's manufacturing sector (mainly steel) was contributing about $50 \%$ of the Gross Geographic Product. By the end of the 1980s the government had privatised Iscor, which meant that many people working in the steel and coal industries lost their jobs.
In response, the local government and business obtained subsidies that the apartheid government made available for decentralised industries and settled several Chinese industries in the textile industry in the area in the early 1990s (Todes, 2002). By 1994 there were approximately 140 Chinese companies (mainly textile and plastic manufacturing) operating in Newcastle. However, as the post-apartheid government systematically reduced the industry subsidies and textile-related import taxes from 1994, the textile industry also came under pressure. Nonetheless, the municipality managed to retain many of the textile industries, developed an excellent relationship with the existing industrialists and marketed the area well in China. Newcastle also slowly built capacity in other manufacturing subsectors and actively pursued other economic sectors (Binns \& Nel, 2003).

The Newcastle municipal area is home to 390,000 people. Annual economic growth was only $0.2 \%$ per annum between 1996 and 2018. Despite this slow growth, Newcastle has avoided decline and, to some degree, managed a transition from mining to textiles to the manufacturing of niche materials (chemicals and paper). Interviewees in our study were quick to point out that coalition governments and good governance were central features of managing these transitions between 1994 and 2016. A common response during interviews was "local government and business had excellent relationships." The good relationship with the chamber of commerce and industrialists in China (evidenced, for example, by a long-standing LED official learning Mandarin) contributed to this success. However, the value of these governance and network gains has come under pressure as the local government has struggled to maintain good governance since 2016. After the 2016 local government elections, the ANC had a majority and no further need for a coalition. The new majority government did not comply with good governance principles and did not value the earlier economic partnerships. High staff turnover, the retirement of the LED official mentioned above, political infighting in the ruling party, weak leadership (because of failure to appoint a permanent municipal manager and chief financial officer) since 2016 have further complicated matters. Ensuring Newcastle's economic viability has become far more challenging than it was five years ago. The editor of the local newspaper said that, because of the "lack of strategic ways to deal with problems, people of Newcastle started working in silos"). This silo mentality stands in contrast to the early attempts to create networks inside and outside the municipality to deal with the economic transition. An official at the municipality explained the problem since 2016 as "a lack of engagement between the municipality and business elite" and "a lack of network governance because there are no relationships across sectors, no political leadership." The failure to build appropriate networks also contributed to industrialists considering alternative locations. The former economic development manager at the Newcastle municipality 
said: "The factories are also all moving to Lesotho and Swaziland because they comply with the African Growth and Opportunities Act to export to the US." To deal with the financial shortfalls created by the ANC-led local government, council raised property taxes by nearly $100 \%$. This has been greeted with outrage by firms and individual households. This decision will probably force many industrialists to consider relocation. The hike in tariffs and limited engagement with economic development issues have created a unified opposition from business chambers, rate payers and concerned residents.

Local politics have been unstable, and some prominent ANC leaders and councillors in KwaZulu-Natal have been assassinated. This rivalry in the province has also played itself out in Newcastle. In May 2019 a witness in the trial of the Newcastle mayor, who had been charged with the murder of an ANC youth league leader in 2016, was gunned down - the charges against the mayor have since been dropped (Mavuso, 2019). The political rivalry and murders have not helped the local government prioritise economic development and manage the economic transition.

\section{Discussion}

Table 1 compares the profiles of the three case study cities and the different ways they have dealt with mine decline. Newcastle has mostly been successful in finding

Table 1. The case study cities.

\begin{tabular}{|c|c|c|c|}
\hline & Emalahleni & Matjhabeng & Newcastle \\
\hline $\begin{array}{l}\text { Original name, } \\
\text { date founded }\end{array}$ & Witbank (1903) & Welkom (1947) & Newcastle (1865) \\
\hline Population 1996 & 455,228 & 476,763 & 287,659 \\
\hline Population 2016 & 167,361 & 429,113 & 389,117 \\
\hline $\begin{array}{l}\text { Annual economic } \\
\text { growth, } \\
\text { 1996-2018 }\end{array}$ & $1.4 \%$ & $-1.6 \%$ & $0.2 \%$ \\
\hline $\begin{array}{l}\text { Number of } \\
\text { households living } \\
\text { in informal } \\
\text { housing, } 2016\end{array}$ & 34,845 & 22,004 & 5,804 \\
\hline $\begin{array}{l}\text { Main economic } \\
\text { sector }\end{array}$ & $\begin{array}{l}\text { Coal mining and coal-fired } \\
\text { energy generation. }\end{array}$ & Gold mining. & $\begin{array}{l}\text { Originally coal and steel, now } \\
\text { textiles and other } \\
\text { manufacturing. }\end{array}$ \\
\hline $\begin{array}{l}\text { Main economic } \\
\text { risk }\end{array}$ & $\begin{array}{l}\text { Declining demand for coal and } \\
\text { transition to renewables. }\end{array}$ & $\begin{array}{l}\text { Depletion of gold reserves, } \\
\text { cost of deep mining. }\end{array}$ & $\begin{array}{l}\text { Initially, decline in demand for } \\
\text { coal, privatisation of ISCOR. } \\
\text { Later, reduction of import tax } \\
\text { on textiles. }\end{array}$ \\
\hline $\begin{array}{l}\text { Economic nature } \\
\text { of path } \\
\text { dependency }\end{array}$ & $\begin{array}{l}\text { Historical development based } \\
\text { on coal mining. Belief that coal } \\
\text { reserves are inexhaustible. } \\
\text { Long-term environmental } \\
\text { problems, e.g., acid mine } \\
\text { water. Historical low-level } \\
\text { technological skills. }\end{array}$ & $\begin{array}{l}\text { Historical development based } \\
\text { on gold mining. Planned in } \\
\text { between mine dumps. } \\
\text { Historical low-level } \\
\text { technological skills. }\end{array}$ & $\begin{array}{l}\text { Has succeeded in switching } \\
\text { from mining to manufacturing } \\
\text { but remains dependent on } \\
\text { international markets. } \\
\text { Historical low-level } \\
\text { technological skills. }\end{array}$ \\
\hline $\begin{array}{l}\text { Governance } \\
\text { nature of path } \\
\text { dependency }\end{array}$ & $\begin{array}{l}\text { Planning system focusing on } \\
\text { steering and not rowing. } \\
\text { National government support } \\
\text { promised, but nothing has } \\
\text { materialised. }\end{array}$ & $\begin{array}{l}\text { Planning system focusing on } \\
\text { steering and not rowing. Long } \\
\text { history of limited support from } \\
\text { national government. }\end{array}$ & $\begin{array}{l}\text { Despite planning system } \\
\text { focusing on steering and not } \\
\text { rowing, municipality built } \\
\text { industrial networks. } \\
\text { Government support for the } \\
\text { first transition. Further } \\
\text { national government support } \\
\text { unlikely. }\end{array}$ \\
\hline
\end{tabular}


Table 1. (Cont.) The case study cities.

\begin{tabular}{llll}
\hline & Emalahleni & Matjhabeng & Newcastle \\
\hline Nature of inter- & A national plan for a just & A local plan for revitalising the & Historically managed to \\
dependencies & transition dependent on & economy dependent on the & benefit from national \\
& national government funding & national government and & government \\
& and the buy-in of the private & private-sector funding. & interdependencies.
\end{tabular}
$\begin{array}{ll}\text { State of 'good } & \text { Financial management and } \\ \text { governance' } & \text { service delivery problems. }\end{array}$

Intergovernmental National plan for economic governance transition exists, but with little local buy-in.

\section{Nature and Local plans do not consider effectiveness of local governance mine closure and a post-closure economy.} and planning

Network governance

Virtually no reference to this in local planning. Some evidence in national planning for a just transition.

Informal settlements, private sector providing water, and allegations of corruption.
Financial management and service delivery problems.

Various plans have assumed intergovernmental funding but it has not materialised.

Much emphasis on finding a single alternative to mining. Value of regional services function lost.

Absent. Expectation is that national government will provide investment for a transition.

Informal settlements and allegations of corruption.
Up to 2016 ample evidence of good governance. Since then a series of problems.

First transition heavily dependent on using a national instrument to help switch from mining to textiles.

Local plans have always included, or been driven by, industrialists and the local chamber of commerce.

Historically, excellent example with links to China and excellent relationships with local chamber of commerce. These aspects have been under pressure since 2016.

Breakdown of relationships with the private sector. Private sector mobilising with other spheres of society. alternatives to coal mining and the related steel manufacturing industry. In contrast, Matjhabeng, despite setting up various bodies outside the ambit of government, has failed to develop an industrial alternative to mining. In Emalahleni there is scant local recognition of the looming mine closure, though there have been some national responses aimed at ensuring a just transition in this city.

Several factors affect the potential economic transitions in these three case study cities. Firstly, the colonial economic emphasis on resource extraction, as opposed to local beneficiation (creating high value goods), persists in the three cities, although some beneficiation did occur in Emalahleni and Newcastle. For example, coal production in Emalahleni is directly associated with power generation and a steel industry did initially develop but failed in 2015. South Africa has seen very little beneficiation of gold. Some attempts were made in Matjhabeng, such as creating a jewellery hub, but the outcomes have been dismal. Neither Emalahleni nor Newcastle has been able to sustain initial attempts to create a viable steel industry (although the steel mill in Newcastle, now owned by ArcelorMittal, still functions).

Secondly, these cities have long been dependent on a single industry. The adverse effects that mining can have on a country, referred to as the 'resource curse' or the 'Dutch Disease,' are well known. At a local level, the effect can be to make local decision-makers overconfident and unable to anticipate decline (Marais \& De Lange, 2021). Matjhabeng is a prime example. The first retrenchments in 1991 came as a surprise to many, although the decline in the gold reserves and an 'overheated' global market were evident. The worst scenario Matjhabeng imagined at the end 1989 was not nearly as bad as the reality on the ground 10 years later (Marais, 2013b). The long dependence on gold has blinded the municipality to the possibility of decline and the need to choose a new path. Many of Matjhabeng's plans focus on finding a single large industry to replace mining. The latest plan does not consider the value of the regional service function of Welkom. The plans assume a magical replacement for mining instead of thinking about the economic diversification that has already occurred or focusing on a range of small initiatives. The inability to imagine potential change is also evident in Emalahleni. Despite national attempts to achieve a just transition in this city, little effort to deal with the risk of decline can be seen at local level. The Emalahleni IDP underplays the risk of coal demand falling. The historical focus on a single sector in 
both Emalahleni and Matjhabeng seems entrenched in future planning, blinding the governance structures to more viable alternatives. Newcastle, on the other hand, shows evidence that it is indeed possible to break the path dependency.

Thirdly, all three cities need to develop plans that consider the long-term implications of mining (Erikson, 1994). The environmental and health risks of living between the mine dumps remain a reality. A prime example is the Merriespruit disaster of 1994: A slimes dam from a non-operational mine burst during a flash flood and killed 17 people in the Merriespruit suburb in the town of Virginia in Matjhabeng. Although the closure of the mines and the coal-fired power stations might reduce air pollution, the effects of acid mine water and underground fires will be a reality in Emalahleni for a long time. People in all three of these cities will have to live with the adverse effects of mining on economic and spatial potential for a long time.

Fourthly, all three cities' economic transitions depend on old skills. In Newcastle, the transition from coal and steel to textiles helped to ensure that low-skilled workers did find work. In Matjhabeng this was more difficult. Mineworkers' skills are not conducive either to finding work in other sectors or to creating new entrepreneurs. Economic transitions require new skills sets and the secondary status of our three case study cities means that although they have some satellite campuses of universities in the metro cities, they do not have mainstream universities to fall back on, to build the skills needed for economic transition. At the same time, many of their Further Education and Training colleges are dysfunctional and do not align well with the local demand for skills.

In addition to the problems associated with economic transition, there are also governance problems. The NPM-based focus on steering results in IDPs that have many goals but lack an understanding of the current economy and how difficult it is to change it. The focus on steering means that the plans are over-idealistic, making implementation extremely difficult. Matjhabeng has made various unrealistic plans, such as the idea of building an international freight airport or, more problematically, the Phakisa racetrack, which was constructed but has become dysfunctional. The steering approach also leads to ignoring an existing problem, as Emalahleni does. Neither Emalahleni nor Matjhabeng have functional partnerships with the business community. Newcastle's success in breaking path dependency contrasts with the NPM steering approach, as can be seen in the actions of the LED official who created partnerships with the local business chamber and even learned Mandarin to create partnerships with Chinese businesspeople. A further problem caused by the focus on planning and steering is that it blinds decision-makers to the economic transitions that occur spontaneously without much planning. All three cities have developed regional services functions as part of a natural process. Yet existing plans often ignore the value of this and do not consider using it as an economic asset for the future.

The problem becomes bigger with capacity constraints. It is this lack of capacity, in conjunction with a steering-focused planning approach, that underlies the inability at local level to find appropriate economic alternatives, as has happened in Emalahleni and Matjhabeng. Those two towns have had very long periods of poor governance, reflected in the lack of unqualified audited financial statements, being run by an administrator, high levels of corruption, and high staff turnover and political appointments.

Economic transitions require an understanding of interdependencies and network steering. However, the rigidity of intergovernmental relationships and the inability to manage networks are evident from the three case studies. Newcastle benefited from the apartheid government's decentralisation subsidies in the early 1990s, but there is currently no national support for economic transitions in Emalahleni and Matjhabeng. There is an expectation that the current national focus on a just transition will provide a framework to help Emalahleni. Again, the focus is on a plan that emphasises steering rather than building the networks that would facilitate a transition. In Matjhabeng, the dominant thinking is that a new plan (an example of steering) will revitalise the economy. This plan is heavily dependent on the national government and private-sector investment, neither of which has been actively sought by decision-makers in the area. In both Emalahleni and Matjhabeng, there is a lack of network steering and the focus remains on a plan. Furthermore, the secondary cities tend to simplify co-operative governance to a process of acquiring funding from other spheres of government. Matjhabeng's LED plan depends mainly on this assumption. And the transition plan that the national government is developing for Emalahleni is a danger because it might be inappropriate to the local situation. To some degree, Newcastle has managed to find appropriate intergovernmental funding for its first transition from mining to textiles. Managing the second transition away from textiles, as the lifting of import taxes will make the industry in Newcastle vulnerable, might be more difficult. A focus on planning can make planners overlook the need to work with nearby municipalities. Furthermore, the planning approach described above depends on national targets. In practice, municipalities and provincial governments must align their plans with the National Development Plan. This requirement means that much emphasis is on the planning process (steering) rather than finding practical local ways of managing an economic transition.

Poor governance and an increase in informality are evident. Newcastle had a stint of good governance up to 2016, but good governance needs to be maintained. Newcastle showed how a municipality could use its municipal finance to help economic transitions by finding a balance between basic infrastructure and infrastructure for business development. Coalition 
governments enabled political parties to contribute to economic development in Newcastle. However, in 2016 one party received a council majority and did not see the value of engaging the other parties in decision-making. Governance problems also include being managed by an administrator (in Emalahleni), a high turnover of municipal managers (in Matjhabeng) and mayors not completing their terms (in Matjhabeng). Evidence of governance informality can be seen in the growth of informal settlements in Emalahleni as a result of the municipality's inability to deal with the large influx of job seekers, and the alleged cases of corruption in all three cities.

\section{Conclusion}

The future of many secondary cities depends on their ability to manage economic transition. Governing a city in the course of economic transition is difficult. This article looked at evidence from three secondary cities in South Africa that have been, or are, mine dependent. The three case studies illustrate path dependency, interdependencies and governance informality.

The economic path dependencies include the historical colonial structure of the economy that emphasised extraction rather than beneficiation, the long dependence on a single economic sector, and the low-level technology associated with mining that does not foster local technological change. The effects of living with the environmental damage caused by mining are beyond the scope of this article to discuss, other than to note that they obviously compound the three cities' problems. The path dependency in governance and management (associated with the NPM paradigm) is inappropriate for managing economic transitions. The emphasis on 'steering' (as opposed to 'rowing'), coupled with severe capacity constraints and a lack of good governance, has had unintended consequences. This result has been large-scale unrealistic projects in the case of Matjhabeng and simply ignoring potential economic transition in the case of Emalahleni. The Newcastle municipality, driven by a LED official, offered some encouraging evidence of a network approach to governing the city's economic transition, building relationships with the chamber of commerce and with investors. This city managed to go some way towards a successful economic transition but now looks like losing the initial gains.

Interdependencies developed in these three cities because of the focus on steering in the local government planning system. Some of these interdependencies result from rigid intergovernmental relations, but also from the IDP system, which emphasises steering and not networking and naively assumes that the national government and private sector will automatically offer support.

Governance informality is increasing, with people or organisations replacing the state or taking matters into their own hands. This is evident in the growth of informal settlements, private companies having to do the work of the municipality, for example by providing water, and allegations of corruption. Governance rules have become irrelevant for some.

Rigidity, interdependencies and governance informality are making economic transition difficult for these three cities. We believe that the underlying problem is a planning system that focuses primarily on steering and reinforces these hindrances to good governance. On top of this, the false sense of security created by the mines discourages economic diversification, making economic transition particularly difficult for mining towns such as these.

\section{Acknowledgments}

The authors acknowledge the financial contribution of the South African Cities Network towards conducting these case studies.

\section{Conflict of Interests}

The authors declare no conflict of interests.

\section{References}

Auditor General of South Africa. (2020). Consolidated general report on the audit outcomes of local government (MFMA 2018-19). https://www.agsa. co.za/Portals/0/Reports/MFMA/201819/GR/MFMA \%20GR\%202018-19\%20Final\%20View.pdf

Avis, W. (2016). Urban governance (topic guide). Governance and Social Development Resource Centre.

Bejacovic, P. (2016). Book review: Limits of a postsoviet state-How informality replaces, renegotiates, and reshapes governance in contemporary Ukraine. Financial, Theory and Practice, 40(4), 463-469.

Binns, J., \& Nel, E. (2003). The village in the game park: Community response to the demise of coal mining in KwaZulu-Natal, South Africa. Economic Geography, 79(1), 41-66.

Campbell, M., Nel, V., \& Mpambukeli, T. (2016). Emalahleni. In L. Marais, E. Nel, \& R. Donaldson (Eds.), Secondary cities and development (pp. 49-61). Routledge.

Campbell, M., Nel, V., \& Mpambukeli, T. (2017). A thriving coal mining city in crisis? The governance and spatial planning challenges at Witbank, South Africa. Land Use Policy, 62, 223-231.

Denoon-Stevens, S. (2019). Matjhabeng: Planning in the face of the Free State Goldfields decline. In L. Marais \& V. Nel (Eds.), Space and planning in secondary cities: Reflections from South Africa (pp. 115-140). SUN Press.

Dunleavy, P., Margetts, H., Bastow, S., \& Tinkler, J. (2005). New public management is dead: Long live digitalera governance. Journal of Public Administration Research and Theory, 16(3), 467-494.

Electoral Commission of South Africa. (n.d.). Municipal 
election results. Electoral Commission of South Africa. https://www.elections.org.za/content/Elections/ Municipal-elections-results

Emalahleni Local Municipality. (2021). Integrated development plan.

Erikson, K. (1994). A new species of trouble: Explorations in disaster, trauma, and community. WW Norton.

Garud, R., \& Karnoe, P. (2001). Path dependence and creation. Psychology Press.

Greif, A. (2006). Institutions and the path to the modern economy: Lessons from medieval trade. Cambridge University Press.

Harrison, P. (2001). The genealogy of South Africa's integrated development plan. Third World Planning Review, 23(2), 175-193.

Hendriks, C. (2022). Municipal finances. In L. Marais, P. Burger, M. Campbell, S. Denoon-Stevens, \& D. Van Rooyen (Eds.), Coal and energy in South Africa: Considering a just transition (pp. 196-226). Edinburgh University Press.

Hood, C., \& Peters, G. (2004). The middle aging of new public management: Into the age of paradox? Journal of Public Administration Research and Theory, 14(3), 267-282.

Klijn, E. (2008). Governance and governance networks in Europe: An assessment of ten years of research on the theme. Public Management Review, 10(4), 505-525.

Klijn, E., Koppenjan, J., \& Termeer, K. (1995). Managing networks in the public sector: A theoretical network of managing strategies in policy networks. Public Administration, 73(3), 437-454.

Kuhlmann, S., Bohumill, J., \& Grohs, S. (2008). Evaluating administrative modernization in German local governments: Success or failure of the "new steering model"? Public Administration Review, 68(5), 851-863.

Marais, L. (2013a). The impact of mine downscaling on the Free State Goldfields. Urban Forum, 24(4), 503-521.

Marais, L. (2013b). Resources policy and mine closure in South Africa: The case of the Free State Goldfields. Resources Policy, 38(3), 363-372.

Marais, L. (2016). Local economic development beyond the centre. Local Economy, 31(1/2), 68-82.

Marais, L., Burger, P., Campbell, M., Denoon-Stevens, S., \& Van Rooyen, D. (2022). Coal and energy in South Africa: Considering a just transition. Edinburgh University Press.

Marais, L., \& De Lange, A. (2021). Anticipating and planning for mine closure in South Africa. Futures, 125, Article 102669.

Marais, L., \& Nel, E. (2016). The dangers of growing on gold: Lessons from the history of the Free State Goldfields, South Africa. Local Economy, 31(1/2), 282-298.
Marais, L., Nel, E., \& Donaldson, R. (2016). Secondary cities and development. Routledge.

Mavuso, S. (2019, August 15). Murder charges withdrawn against Newcastle mayor. IOL News. https:// www.iol.co.za/news/politics/breaking-news-murdercharges-withdrawn-against-newcastle-mayor30813483

North, D. (1990). Institutions, institutional change and economic performance. Cambridge University Press.

North, D. (2005). Understanding the process of economic change. Princeton University Press.

Polese, A. (2016). Limits of a post-soviet state: How informality replaces, renegotiates, and reshapes governance in contemporary Ukraine. Ibidem Verlag.

Rhodes, R. (1997). Understanding governance. Open University Press.

Sarmiento, H., \& Tilly, C. (2018). Governance lessons from urban informality. Politics and Governance, 6(1), 199-202.

Sesele, K. (2020). Women and mine decline in the Free State Goldfields. University of the Free State.

Sesele, K., Marais, L., Van Rooyen, D., \& Cloete, J. (2021). Mine decline and women: Reflections from the Free State Goldfields. The Extractive Industries and Society, 8(1), 211-219.

South African Cities Network. (2020). Profiling intermediate cities in South Africa.

Stoker, G. (2006). Public value management: A new paradigm for networked governance. American Review of Public Administration, 36(1), 41-57.

Todes, A. (2002). Industrial restructuring in South Africa: The case of Newcastle. Tijdschrift voor Sociale en Economishe Geografie, 90(4), 379-390.

Van Assche, K., Beunen, R., \& Duineveld, M. (2014). Evolutionary governance theory: An introduction. Springer.

Van Assche, K., Beunen, R., \& Duineveld, M. (2016). An overview of EGT's main concepts. In R. Beunen, K. Van Asche, \& M. Dunineveld (Eds.), Evolutionary governance theory: An introduction (pp. 19-36). Springer.

Van Assche, K., Shtaltovna, A., \& Hornidge, A. K. (2013). Visible and invisible informalities and institutional transformation in the transition countries of Georgia, Romania, and Uzbekistan. In C. Giordano \& N. Hayoz (Eds), Informality in Eastern Europe (pp. 89-118). Peter Lang.

Westoby, P., \& Botes, L. (2020). From marginalisation to destiny: Anger, violence and community protest in South Africa. In P. Westoby \& L. Botes (Eds.), Does community development work? Stories and practice from reconstructed community development in South Africa (pp. 135-152). Practical Action Publishing. 


\section{About the Authors}

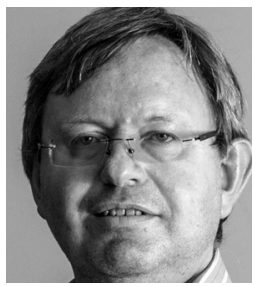

Lochner Marais is a Professor of Development Studies at the Centre for Development Support at the University of the Free State (UFS). He is also an Honorary Professor at the Sustainable Minerals Institute (University of Queensland, Australia). His research interests include housing policy, small cities in towns (mining and renewable towns and cities) and public health focusing on children. In addition to concentrating on each of these themes separately, he focuses on integrating them.

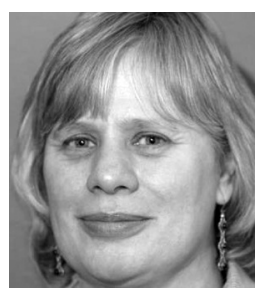

Verna Nel is a registered Urban and Regional Planner who lectures at the University of the Free State. Her undergraduate studies were at Wits University and she completed he postgraduate studies through Unisa. Her key research interests are spatial governance, urban resilience and local economic development and their application in various contexts such as in mining communities and secondary cities.

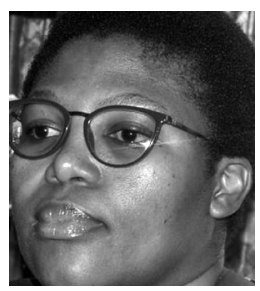

Kholisa Rani is a Researcher and Lecturer at the Centre for Development Support, University of the Free State. She obtained her MSSc (Sociology) in 2006. She has formed part of several national and international research projects and has authored and co-authored several journal articles and book chapters. Her research and teaching areas of interest are socio-economic research, community development research, gender, and the environment, focusing primarily on qualitative research methods.

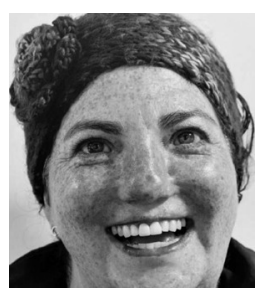

Deidré van Rooyen (PhD) works as a Senior Researcher for the Centre for Development Support at the University of the Free State (www.ufs.ac.za/cds). She completed her MA in Gender studies and her PhD in Development Studies. She has authored, co-authored and compiled numerous research reports and published widely in peer-reviewed conference papers, journals or chapters in books. Her specialisation fields of research are Social Entrepreneurship and Local Economic Development in small towns.

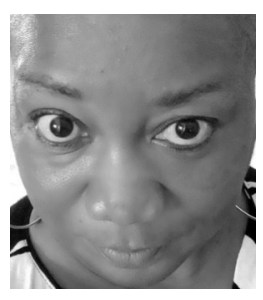

Kentse Sesele is a Post-Doctoral Fellow at the Centre for Development Support at the University of Free State. She is a published Author in the areas of mining policy, feminism and mining decline. She has worked as a Consultant in the public management sphere. She has also served on various boards, including one of the municipal entities.

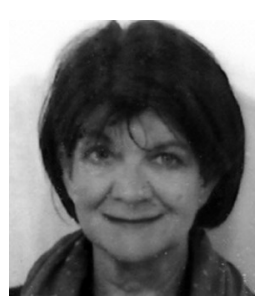

Phia van der Watt is a Community Development Practitioner, specialising in intergenerational communal wounding and healing. She applies her approach in helping professionals and research on the impact of mining on the surrounding communities. She is currently a post-doctoral fellow at the Centre for Development Support at the University of the Free State.

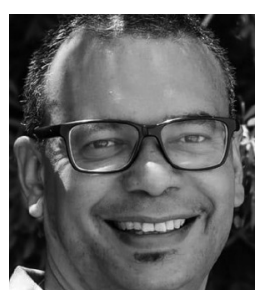

Lyndon du Plessis is Senior Lecturer and Head of Department in the Department of Public Administration and Management at the University of the Free State, Bloemfontein, South Africa. His areas of interest include decentralised governance with specific reference to the challenges pertaining to maintaining good governance practices and effective policy implementation. 